\title{
Evaluating continuous application of treated sludge on soil and plant productivity
}

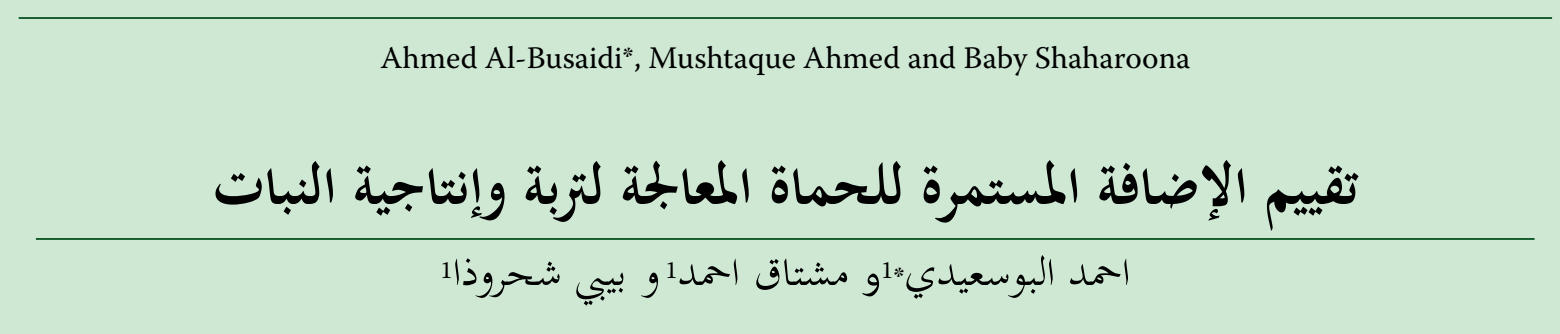

Abstract. Kala Compost is a mixture of treated sewage bio-solids and green wastes. It can improve soil fertility and plant growth. However, long-term application of treated sewage bio-solids could result in heavy metals accumulation and some health problems. The objective of this study was to evaluate the effect of a long run application of Kala compost mixed with chemical fertilizer on soil and plant productivity. Soil and plant (mainly cucumber) samples were taken from 12 greenhouses that received Kala compost continuously for the last five years. No symptoms of physical or chemical problems were observed in the greenhouses and measured soil samples. Moreover, the soil had sufficient values of different nutrients for plant growth and all measured micronutrients (heavy metals) were within the safe limit and below the range of the international standards. An excellent growth was observed in all grown plants and no symptoms of elements deficiency were found. Chemical analysis of fruit samples did not show any accumulation of heavy metals and all measured elements were within the safe limit and did not exceed the international standards. It can be concluded that Kala compost was a good media for plant growth that can enrich the soil with different elements needed for higher yield. However, more monitoring is needed with treated bio-solid application but good management could be the key to avoid any adverse effect of any contaminant.

KEYwORDS: Kala compost; heavy metal; plant growth

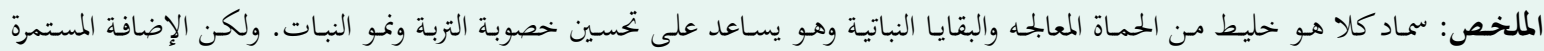

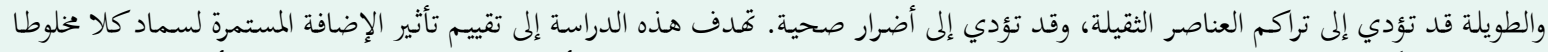

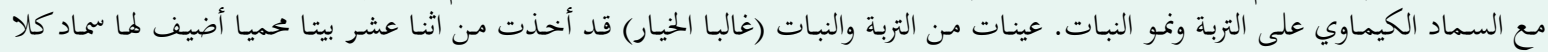

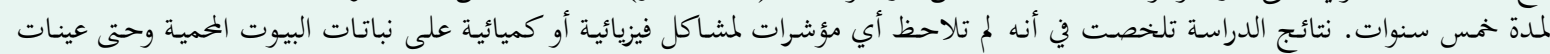

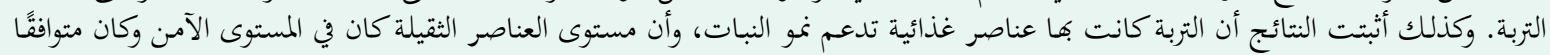

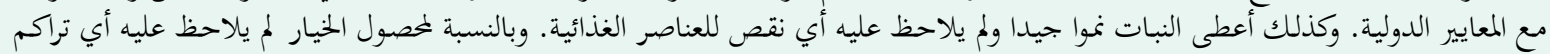

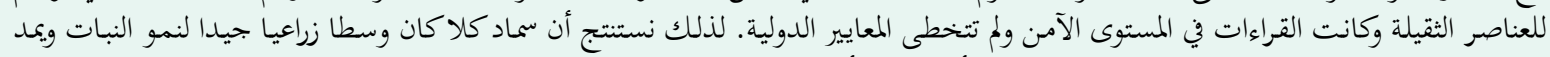

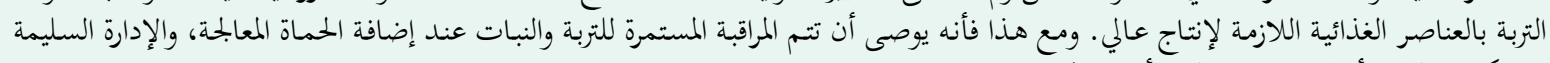

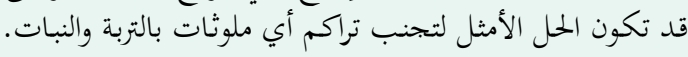

$$
\begin{aligned}
& \text { الكلمات المفناحيه: سماد كلاز العناصر الثقيلة ; نمو النبات }
\end{aligned}
$$

\section{Introduction}

S ewage sludge is a byproduct of sewage treatment processes, comprised of organic materials, macro and micronutrients, some toxic metals, microorganisms, and micro-pollutants. The nutrient elements present in the sewage sludge could help in fulfillment of the nutrientional requirement of the plants and the organic matter could act as soil conditioner. This is due to the fact that sewage sludge contains high amounts of plant nutrients for instance, nitrogen, phosphorus, calcium and magnesium but usually these are deficient in potassium (Logan and Harrison, 1995). Usually, the applications of sewage sludge could improve soil physical properties such as porosity, bulk density, aggregate

* Ahmed Al-Busaidi ( Sultan Qaboos University, College of Agricultural and Marine Sciences, Department of Soils, Water and Agricultural Engineering. Box 34, Al-Khod 123. Sultanate of Oman. email: ahmed99@squ.edu.om stability and water holding capacity. Nonetheless, its continuous application could result in the accumulation of potentially toxic heavy metals. The accumulation and availability of heavy metals associated with sewage sludge is strongly influenced by soil $\mathrm{pH}$, cation exchange capacity, organic matter, and mobility and speciation of specific metals (Korboulewsky et al., 2002). Generally, the application of higher amounts of sewage sludge to soil has been found to increase the bioavailability of heavy metals, however, the low doses of sewage sludge are not found to cause significant increases in heavy metal concentrations (Kulling, 2001). Sewage sludge amendment increases the production of a variety of plants including vegetables, cereals, grasses and trees (Ramulu, 2002). The consumption of such plants might pose a serious risk to human health (Hue and Ranjith, 1994).

In Oman, Haya Water company is mixing treated sewage bio-solids with green waste to produce compost 
Table 1. Elemental concentrations in irrigation water.

\begin{tabular}{lcccccccccc}
\multicolumn{1}{c}{ Parameter } & $\mathbf{p H}$ & $\mathbf{E C w}$ & $\mathbf{C a}$ & $\mathbf{K}$ & $\mathbf{N a}$ & $\mathbf{M g}$ & $\mathbf{P}$ & $\mathbf{F e}$ & $\mathbf{N i}$ \\
Unit & - & $\mathrm{dS} / \mathrm{m}$ & $\mathrm{mg} / \mathrm{L}$ & $\mathrm{mg} / \mathrm{L}$ & $\mathrm{mg} / \mathrm{L}$ & $\mathrm{mg} / \mathrm{L}$ & $\mathrm{mg} / \mathrm{L}$ & $\mathrm{mg} / \mathrm{L}$ & $\mathrm{mg} / \mathrm{L}$ \\
Barka & 8.25 & 1.15 & 44.26 & 4.23 & 97.89 & 33.12 & 0.003 & $<0.002$ & $<0.01$ \\
Hamra & 8.10 & 1.23 & 53.98 & 3.69 & 60.94 & 42.60 & 0.001 & $<0.002$ & $<0.01$ \\
\multicolumn{1}{c}{ Parameter } & $\mathbf{B}$ & $\mathbf{C u}$ & $\mathbf{Z n}$ & $\mathbf{P b}$ & $\mathbf{M o}$ & $\mathbf{C o}$ & $\mathbf{C d}$ & $\mathbf{C r}$ & $\mathbf{H g}$ \\
Unit & $\mathrm{mg} / \mathrm{L}$ & $\mathrm{mg} / \mathrm{L}$ & $\mathrm{mg} / \mathrm{L}$ & $\mathrm{mg} / \mathrm{L}$ & $\mathrm{mg} / \mathrm{L}$ & $\mathrm{mg} / \mathrm{L}$ & $\mathrm{mg} / \mathrm{L}$ & $\mathrm{mg} / \mathrm{L}$ & $\mu \mathrm{\mu g} / \mathrm{L}$ \\
Barka & 0.31 & 0.003 & 0.011 & $<0.003$ & $<0.010$ & $<0.001$ & $<0.001$ & 0.032 & $<0.03$ \\
Hamra & 0.25 & 0.002 & $<0.004$ & $<0.003$ & $<0.010$ & $<0.001$ & $<0.001$ & $<0.006$ & $<0.03$ \\
Recommended * & $\mathbf{0 . 7 5}$ & $\mathbf{0 . 0 5 - 1}$ & $\mathbf{2 - 5}$ & $\mathbf{0 . 1}$ & - & - & $\mathbf{0 . 0 1}$ & $\mathbf{0 . 1}$ &
\end{tabular}

"Source: CPCB (2002)

called KALA compost that can be used for agriculture, landscaping and for individual gardens. However, a high application of sewage bio-solids could result in heavy metals accumulation and many health problems. Therefore, the objective of this study was to evaluate farmer practices in continuous application of treated sludge (Kala compost) on soil and plant productivity. The work could help the interested stakeholders to understand the research achievements in soil fertility and quality horticultural crop production through regulated usage of Kala compost.

\section{Materials and methods}

The study was carried out in two farms with 59 greenhouses. The first farm is located in the Barka area (B) in the Al-Batinah region where Kala compost has been applied continuously for the last 5 years. Kala compost made of biosolids, green waste, horse bedding and scrap wood. It has been used as a fertilizer for different crops grown in open field and greenhouses. Moreover, other fertilizers such as chemical fertilizer (NPK) and chicken manure have been applied too. The rate of application was $20 \mathrm{~kg}$ of Kala compost $+20 \mathrm{~kg}$ of chicken manure + 3 kg of N:P:K (15:15:15) fertilizer per $41.5 \mathrm{~m}^{2}$. Many vegetables and fruits have been grown in the farm such as cucumber, cabbage, eggplant, hot pepper, date palm, mango, lemon, etc. The study was focused on 12 greenhouses where the farmer has been growing cucumber (Cucumis sativus). The site was visited twice (January \& June 2015) and each time soil, water and plant samples were taken from all greenhouses.

The second farm was in the Al-Hamra $(\mathrm{H})$ area in the Dakhiliyah region where the Kala compost has been applied continuously for last 5 years. The farm is mainly

Table 2. Soil textural analysis.

$\begin{array}{ccccl}\text { Location } & \begin{array}{c}\text { Sand } \\ (\mathbf{\%})\end{array} & \begin{array}{c}\text { Clay } \\ (\mathbf{\%})\end{array} & \begin{array}{c}\text { Silt } \\ \mathbf{( \% )}\end{array} & \text { Texture } \\ \text { Barka } & 36.4 & 8.8 & 54.8 & \text { Silt loam } \\ \text { Hamra } & 51.6 & 5.2 & 43.2 & \text { Sandy loam }\end{array}$

greenhouses with cucumber (Cucumis sativus) plants. Excellent yields were obtained and commercially sold to different markets. For the study, 12 greenhouses were selected and samples for soil, water and plants were taken in both visits during January and June 2015.

Soils extracts were obtained using the saturation paste method while plants extracts were obtained using acid digestion method. Final extracts were sent to reputed laboratory for macro and micro elements analysis.

\section{Results}

\section{Irrigation Water}

Both farms are irrigated by groundwater using the drip irrigation system. The quality of water is good for irrigation with a low concentration of salts (Table 1). If the soil is well managed, it is not expected to have problems with salt accumulation. Comparing heavy metals concentrations with recommended values mentioned in Table 1, it can be seen that all measured elements are below the maximum limit which means this water is suitable for agriculture. However, Boron was detected which may cause some accumulation in the soil with the long term application of this water if poor management is practiced. Nevertheless, the higher concentrations of toxic metals do not necessarily mean toxicity to the plants. As metals availability and uptake by plants in agricultural environments is related to i) the activity of metal ions in the solution, which depends upon $\mathrm{pH}, \mathrm{pE}$, concentration and composition, ii) the concentration and ratios of accompanying elements that influence the uptake and transport of that metal ion by roots, and iii) numerous environmental factors (Pessarakli, 1999).

\section{Soil Samples}

The general soils of both locations are loamy soil which is one of the best types of soils for agricultural practices (Table 2). Barka soil has more silt which can absorb and keep more water whereas Al-Hamra soil has more sand that could enhance leaching process of extra salts and improve soil aeration. Additions of organic fertilizers enhance soil fertility and improve soil structure. 
Table 3. Soil elemental analysis. Concentrations are in mg.kg ${ }^{-1}(\mathrm{ppm})$.

\begin{tabular}{cccccccc|} 
& Ca & P & K & Na & Mg & N \\
Min & 5.07 & 0.23 & 3.47 & 3.68 & 2.58 & 1500 \\
Max & 133.24 & 2.13 & 248.87 & 121.67 & 44.16 & 11200 \\
Average $(\mathbf{n = 2 8 )}$ & 32.03 & 0.87 & 75.90 & 42.32 & 16.65 & 5600 \\
\hline
\end{tabular}

Ramulu (2002) found that organic matter added to the soil as sewage sludge composts improved the soil properties, such as bulk density, porosity and water holding capacity. In general, the higher organic matter proportion in sludge decreased bulk density and increased the aggregate stability. These improvements in soil physical properties increased water-holding capacity by promoting higher water retention in sludge-amended soils (Ojeda et al., 2003).

Using different fertilizers to improve soil fertility is good but over-application of any fertilizer could cause salt accumulation in the soil surface. From (Fig. 1), it can be seen that most soils had high values of soil salinity at the beginning of the growing season, which comes normally from heavy application of different fertilizers such as chemical fertilizer (NPK), organic manure (chicken) and Kala compost. Those salts were found in the greenhouses that were prepared for the new season or plants were in the initial stage of growth. Over application of irrigation water was the main reason for decreasing soil salinity and leaching down or moving salts away from root zones which can be seen at the end of the growing season in the greenhouses that had big or harvested plants (Fig. 2). Moreover, those salts can be considered as nutrients that are needed by plants and will be consumed by the time. In general, organic compost such as Kala is rich with nutrients which could increase the salinity value but at the same time those salts will be slowly released to the soil and support plant growth for a long time without any problem of toxicity. This finding was also supported by Kulling (2001) and Logan and Harrison (1995) when they reported that sewage sludge is composed of organic compounds, macronutrients, wide range of micronutrients, non-essential trace metals, organic micro pollutants and microorganisms. The macronutrients in sewage sludge serve as a good source of plant nutrients and the organic constituents provide beneficial soil conditioning properties.

More salts in the soil mean more nutrients are available for the plant. An adequate amount of major nutri-

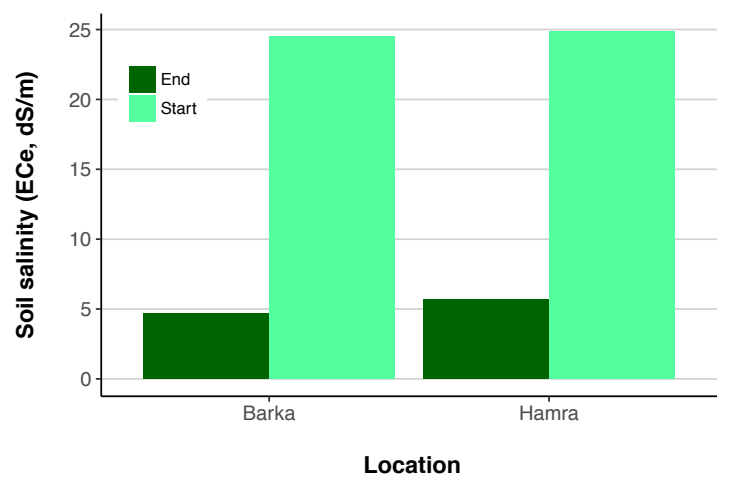

Figure 1. Soil salinity at the beginning and at the end of the growing season.

ents (NPK) can be seen in the soil samples (Table 3). However, presence in high amount of some salts like $\mathrm{Na}$ could cause toxicity problem for the plants. Therefore, leaching and good management are required to get the full benefits of all nutrients with maximum yield.

This finding is also supported by Hernandez et al. (1991) when they conducted a study to analyze the influence of sewage sludge application to a Calciorthid soil on the soil availability of macronutrients $(\mathrm{N}, \mathrm{P}$, and $\mathrm{K})$ and heavy metals ( $\mathrm{Fe}, \mathrm{Cu}, \mathrm{Zn}, \mathrm{Mn}, \mathrm{Ni}, \mathrm{Cr}, \mathrm{Cd}$, and $\mathrm{Pb}$ ). Total $\mathrm{N}$ and extractable $\mathrm{N}$ and $\mathrm{P}$ contents increased in the sludge-amended soil.

Micronutrients or heavy metals are the most critical elements in the soil. Their values could be indicators for soil fertility or contamination. From (Fig. 2), it can be seen that values for all micronutrients and heavy metals are within the acceptable ranges and even the maximum values for all measured elements were less than the international acceptable maximum values (Table 4). Some values were found in soils that had a high amount of salts indicating they were close to fertilizer contents, even though the concentrations of heavy metals did not exceed the international standards. High value of Boron could be resulting from continuous accumulation of

Table 4. Micronutrients concentrations in the studied soils. All concentrations are in ppm except $\mathrm{Hg}$ in ppb.

$\begin{array}{lcccccccccccc}\text { Parameter } & \text { Fe } & \text { Ni } & \text { B } & \mathbf{C u} & \mathbf{Z n} & \mathbf{P b} & \text { Mo } & \text { Co } & \text { Cd } & \text { Cr } & \text { Hg } \\ \text { Min } & 0.000 & 0.004 & 0.060 & 0.005 & 0.001 & <0.001 & 0.010 & 0.000 & <0.0003 & <0.002 & <0.01 \\ \text { Max } & 0.039 & 0.103 & 0.496 & 0.102 & 0.096 & <0.001 & 0.062 & 0.023 & <0.0003 & <0.002 & <0.01 \\ \text { Average } & 0.012 & 0.024 & 0.238 & 0.037 & 0.029 & <0.001 & 0.027 & 0.003 & <0.0003 & <0.002 & <0.01 \\ \text { Recommended* }^{*} & \mathbf{1 0 0 0} & \mathbf{7 5 - 1 0 0} & & \mathbf{5 0 - 1 4 0} & \mathbf{2 0 0 - 3 0 0} & \mathbf{3 0 0} & - & \text { Not fixed } & \mathbf{3 - 6} & \mathbf{1 5 0} & -\end{array}$

"Source: CPCB (2002). 


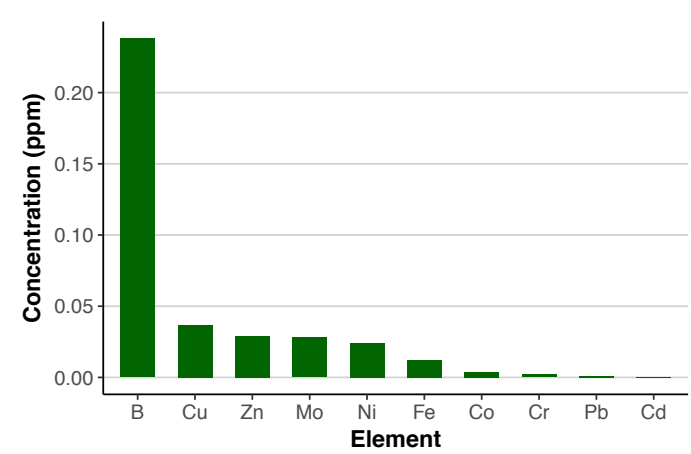

Figure 2. Average concentrations of soils micronutrients.

Boron from irrigation water as shown in Table 1. These findings were in parallel with Hernandez et al. (1991) when they found that the extractability of $\mathrm{Fe}, \mathrm{Cu}, \mathrm{Mn}$, $\mathrm{Zn}$ and $\mathrm{Pb}$ increased due to sludge application as compared to the control.

\section{Plant samples}

Plants growth and yields were excellent in both farms. The mature plants looked healthy and full of fruits (Fig. 3). Initial salts applied to the soil as fertilizer were pushed away from the root zone creating enriched environment for growth around the plants. Therefore a high yield resulted without facing any problem of nutrient deficiency. It seems that Kala compost and other fertilizers were creating a good environment for plants by releasing multi-nutrients, reducing evaporation and keeping much water in the root zone. In addition, high rates of sludge application could increase the cation exchange capacity, which could help to retain essential plant nutrients within the rooting zone due to additional cation binding sites (Soon, 1981).

The harvested cucumber had a high amount of good nutrients such as $\mathrm{Ca}, \mathrm{K}, \mathrm{Mg}$ and $\mathrm{P}$ (Table 5). Those values resulted from rich soil that supported plant growth as shown in Tables 3 and 4. Good results were also found in Nielson et al. (1998) study when the municipal biosolids were added to cultivate carrots and chard on irrigated soils. A significant increase in yield was found in plants growing bio-solid amended soil as compared to those grown in non-amended soil. In addition, a similar study with cotton (G. hirsutum) also showed advancement of flowering and fruiting by $2-3$ weeks under sludge-amended soil as compared to fertilizer amended ones (Tsakou et al., 2001). The faster development and greater biomass production in plants grown in sludge-amended soil may be responsible for an early reproductive cycle. Moreover, the complex of organic and the inorganic compounds of sewage were broken down into simpler forms, and thus the final treated sludge became useful and beneficial to the seedling growth (Metcalf and Eddy, 2003).

Long-run consumption of some heavy metals in vegetables or fruits could cause some health problems. As it can be seen from (Fig. 4) that all measured heavy metals were within the acceptable levels, even the maximum values were below the recommended values (Table 6). It can be noticed that nickel values are high and exceed the international limits. However, its original values in the soil samples were low and within the international standards. an excess amount of this element in the fruits could be related to human activities and plant absorption ratio. If it is present in high values in the soil, this may cause some growth problems. Extra samples were taken from cabbage plant and no problem was observed in plant growth or heavy metals concentrations even $\mathrm{Ni}$ concentration was low $(3 \mathrm{mg} / \mathrm{kg}$ ) and within the recommended values. Nickel is a transition metal and found in natural soils at trace concentrations. However, its concentration is increasing in certain areas by human

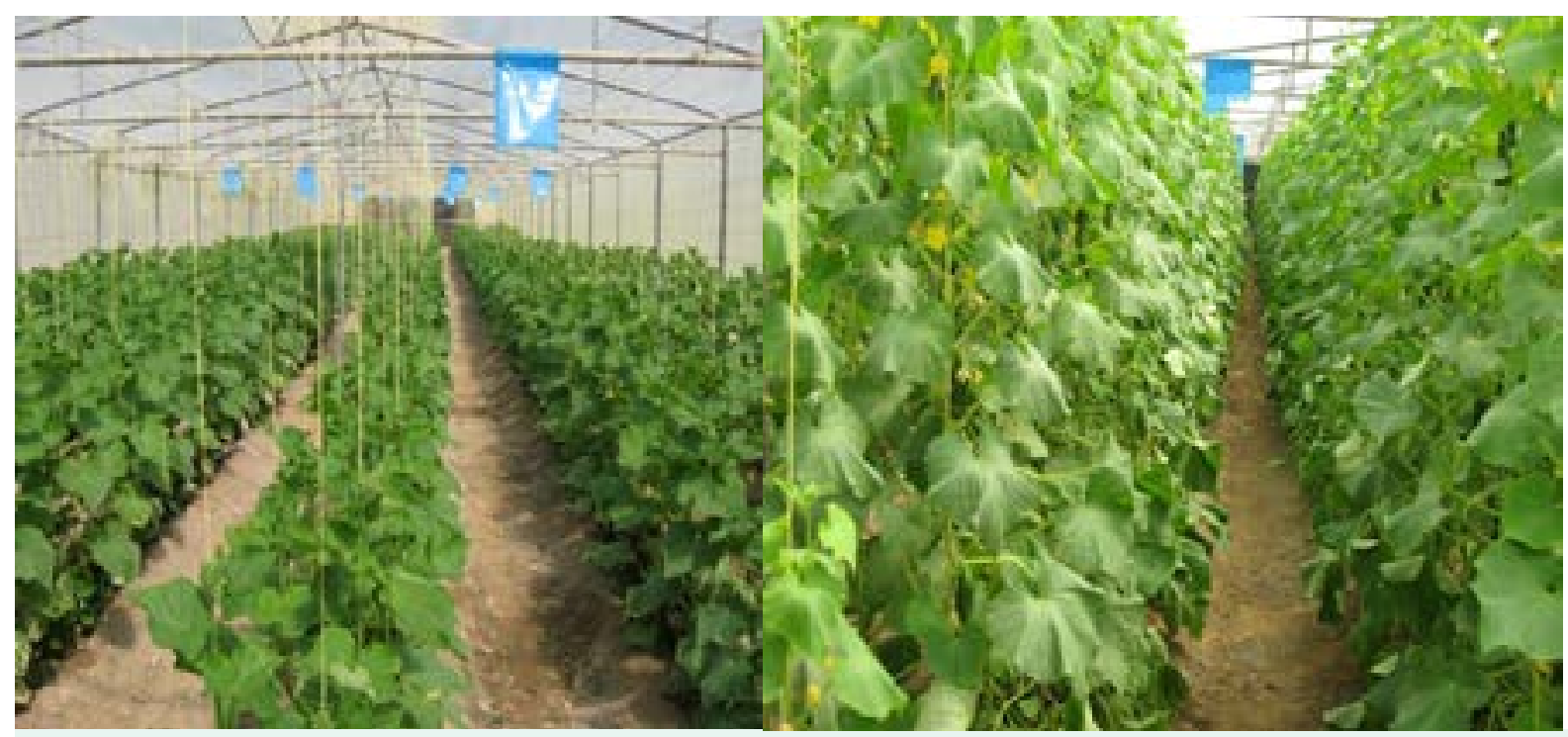

Figure 3. Growing cucumber plants in both farms. 


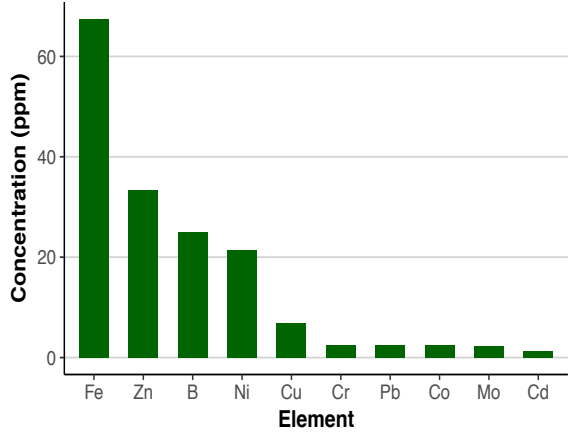

Figure 4. Average concentration of micronutrients in cucumber fruits cultivated on Kala compost.

activities such as mining works, emission of smelters, burning of coal and oil, sewage, phosphate fertilizers and pesticides. An excess of $\mathrm{Ni}$ in soil causes various physiological alterations and diverse toxicity symptoms such as chlorosis and necrosis in different plant species. Plants grown in high $\mathrm{Ni}$ containing soil showed impairment of nutrient balance and resulted in disorder of cell membrane functions. Other symptoms observed in Ni treated plants were related with changes in water balance.

In general, many factors influence the uptake of metals and include the growing environment, such as temperature, soil $\mathrm{pH}$, soil aeration, Eh condition (particularly of aquatic environment) and fertilization, competition between the plant species, the type of plant its size, the root system, the availability of the elements in the soil or foliar deposits, the type of leaves, soil moisture and plant energy supply to the roots and leaves. Several studies have evaluated the tissue concentrations of nutrients and heavy metals in plants when grown in the sewage sludge amended soil. The accumulation pattern varied with soil type, plant species, phenology and chelating effects of other metals (Mahler et al., 1980).

In Dowdy and Larson's (1975) study, Cd, Zn, Ni, Hg and other toxic metals were high in sweet corn when grown on sludge-amended soil, but the accumulation was less in corn kernels than in leaves and roots. Generally, the accumulation of heavy metals depends on soil managements and plant selectivity. Pescod (1992) concluded that the concentrations of heavy metals in seeds were within normal level when treated wastewater effluent was used. Such results make it clear that heavy metal
Table 5. Soil textural analysis. All values in $\mathrm{mg} \cdot \mathrm{kg}^{-1}(\mathrm{ppm})$

\begin{tabular}{llllll} 
Element & Ca & K & Na & Mg & P \\
Min & 2500 & 11300 & 1300 & 2050 & 3500 \\
Max & 5850 & 23900 & 6000 & 2900 & 5650 \\
$\begin{array}{l}\text { Average } \\
(\mathrm{n}=8)\end{array}$ & 4343 & 18771 & 2829 & 2514 & 4450 \\
\hline
\end{tabular}

in soil are not readily bio-available for crop uptake and do not represent a threat to quality of crop consumption.

\section{Conclusion}

It can be concluded that fertilizers and composts such as Kala applied in this study were good conditioners for the soil as they supported plants with many elements needed for high yield. Soil and plant chemical analysis did not show any indications of heavy metal accumulation. Five years of application of Kala compost did not cause any environmental or potential human health problems. Therefore, we believe it is safe to apply Kala compost to some agriculture crops if good management is applied. Moreover, it is recommended that long-term records on application of Kala compost alone is required, so clear findings can be obtained.

\section{Acknowledgements}

The authors would like to thank staff from Sultan Qaboos University for their support in collecting and analyzing soil, water and plant samples. Special thanks to Haya Water Company and USAID (FABRI) for their financial support.

\section{References}

CPCB (Central Pollution Control Board), 2002. Parivesh, Newsletter from CPCB. Available at http://cpcb.nic. in/IIMLko.pdf

Dowdy, R.H. and Larson, W.E. 1975. The availability of sludge borne heavy metals to various vegetable crops. J. Environ. Qual., 4: 278-282.

Hernandez, T., Moreno, J.I., and Costa, F. 1991. Influence of sewage sludge application on crop yields and heavy metal availability. Soil Sci. Plant Nutr., 37 (2): 201-210.

Hue, N.V. and Ranjith, S.A. 1994. Sewage sludges in Ha-

Table 6. Micronutrients concentrations in the studied soils. All in ppm except $\mathrm{Hg}$ in ppb.

\begin{tabular}{lccccccccccc}
\multicolumn{1}{c}{ Parameter } & Fe & Ni & B & Cu & Zn & Pb & Mo & Co & Cd & Cr \\
Min & 38.5 & 3 & 25 & 3.5 & 22 & 2.5 & 2.5 & 2.5 & 1.25 & 2.5 \\
Max & 87 & 40 & 25 & 13 & 52 & 2.5 & 2.5 & 2.5 & 1.25 & 2.5 \\
Average (n=8) & 67.43 & 21.36 & 25 & 6.79 & 33.29 & 2.5 & 2.5 & 2.5 & 1.25 & 2.5 \\
Recommended $^{*}$ & $\mathbf{4 5 0}$ & $\mathbf{5 - 1 0}$ & - & $\mathbf{3 0 - 4 0}$ & $\mathbf{5 0 - 6 0}$ & $\mathbf{2 . 5 - 5}$ & - & - & $\mathbf{1 . 5}$ & $\mathbf{5 - 2 0}$
\end{tabular}

"Source: CPCB (2002). 
waii: chemical composition and reactions with soils and plants. Water Air Soil Pollut., 72: 265-283.

Korboulewsky, N., Dupouyet, S. and Bonin, G. 2002. Environmental risks of applying sewage sludge compost to vineyards: carbon, heavy metals, nitrogen, and phosphorous accumulation. J. Environ. Qual., 31: 1522- 1527.

Kulling, D., Stadelmann, F. and Herter, U. 2001. Sewage Sludge - Fertilizer or Waste? UKWIR Conference, Brussels.

Logan, T.J. and Harrison, B.J. 1995. Physical characteristics of alkaline stabilized sewage sludge (N-vitro soil) and their effects on soil properties. J. Environ. Qual., 24: 153-164.

Mahler, R.J., Bingham, F.T., Sposito, G. and Page, A.L. 1980. Cadmium enriched sewage sludge application to acid and calcareous soils, relation between treatment, $\mathrm{Cd}$ in saturated extracts and $\mathrm{Cd}$ treatment. J. Environ. Qual., 9: 359-364.

Metcalf and Eddy, 2003. Wastewater engineering: treatment, disposal, and reuse, fourth ed. McGraw-Hill Publishing Company Ltd., New York.
Nielson, G.H., Hogue, E.J., Nielson, D.,and Zebarth, B.J. 1998. Evaluation of organic wastes as soil amendments for cultivation of carrot and chard on irrigated sandy soils. Can. J. Soil Sci., 78: 217-225.

Ojeda, G., Alcaniz, J.M. and Ortiz, O. 2003. Runoff and losses by erosion in soils amended with sewage sludge. Land Degrad. Dev., 14 (6): 563-573.

Pescod, M.,1992. Wastewater treatment and use in agriculture. Bull. FAO \#47 (125) (Rome).

Pessarakli, M. 1999. Handbook of plant and crop stress. CRC, USA.

Ramulu, U.S. 2002. Reuse of municipal sewage and sludge in agriculture. Scientific Publishers, Jodhpur, India.

Soon, Y.K. 1981, Solubility and sorption of cadmium in soils amended with sewage sludge. J. Soil Sci., 32: 85-95.

Tsakou, A., Roulia, M. and Christodoulakis, N.S. 2001. Growth of cotton plants (Gossypium hirsutum) as affected by water and sludge from a sewage treatment plant: I. Plant phenology and development. Bull. Environ. Contam. Toxicol., 66: 735-742. 